\title{
MUTICRITERIA ASSESMENT OF POSSIBLE USE OF COMPUTER GAMES IN TEACHING
}

\author{
Mališa R. Žižovića ${ }^{a}$ Katarina G. Plećićb \\ Singidunum University Belgrade, Faculty of Health, \\ Legal and Business Studies, Valjevo, Republic of Serbia, \\ a e-mail: zizovic@gmail.com, \\ ORCID iD: :http://orcid.org/0000-0003-0789-8565 \\ be-mail: kplecic@singidunum.ac.rs, \\ ORCID iD: Dhttp://orcid.org/0000-0002-0153-4069
}

http://dx.doi.org/10.5937/vojtehg65-13000

FIELD: Mathematics

ARTICLE TYPE: Original Scientific Paper

ARTICLE LANGUAGE: English

\section{Summary:}

In this paper we present a multi-criteria evaluation of several possible approaches to organization of studies. A wider use of modern information technology has led to major changes in traditional education. One of them is the development of serious games in order to simulate real business work environment.

The traditional passive education approach trains people for some narrow procedures, and then evaluates them based on their memories of what they have been told. Even when students have successfully mastered facts and procedures, their behavior in real life situations remains uncertain. Games are trying to solve this problem, motivate and promote learning. Their interactive aspect leads to high involvement of participants in game activities, so they no longer have the sole purpose of entertainment, but become a serious learning tool. The possibility to provide entertainment and educational component separates these games from classical, fun games. Also, participants are not passive players. Their decisions and actions directly affect the flow of the game, leading to good or bad results.

To evaluate game application in classroom, a multicriteria analysis was used. It was used for the assessment of possible study forms in order to use benefits of information technology for modernizing and improving teaching and learning processes. The evaluation was made by observing four alternatives, as well as six criteria. The aim of this paper was to make these applications more effective where needed and to indicate apossibility to use them elsewhere.

Key words: multi-criteria analysis, criteria, weights of criteria, games, simulation. 


\section{Introduction}

In the last decade of the previous century, and especially in its last years, the implementation of modern information technologies and methods led to changes in many areas of teaching.

It is generally known that the acceptance of new opportunities and challenges is dominated and forefront by young people. Also, the truth was that decision-makers were generally the elderly, so this possibility of using new technologies did not immediately come to full expression in all places; however, sooner or later, people accept things which make their work efficient.

The paper analyzes the situation in education, in one possible direction in particular - using information technology in teaching through games and simulations which are already been successfully used (there are other approaches to information technology applications, for example (Miljković et al, 2016, pp.1009-1032).

The aim of this paper is to highlight the way how teaching using information technology can be more efficient (where already implemented), and to point to a wide range of possibilities for their application in the areas where information technology has not been used yet.

\section{Games and simulations}

One of the first computer applications were games created for fun. Since such games immediately became popular, first they were used for mass sales of computers and for the implementation of higher classes of computers.

With the Internet expansion, Internet games appeared. Many serious software companies developed Internet games because some of them gathered millions of active players worldwide. Some well-known Internet games are, for example, World of Warcraft, League of Legends, World of Tanks, Runescape, Perfect World, Starcraft, Counter Strike, etc.

Internet games were followed by various services for usage, distribution, promotion, different kinds of protection, etc. This game industry is still very successful today.

Software companies tried to take advantage of the phenomen on that the games are massively accepted by the young and the old alike, and to create games not aimed to be fun only, but also to have another function, such as education. This, too, was successful. Designers of computer games are creating highly motivating environments which players both enjoy and learn in. The concept of gamefication (Shank, 2013) is introduced. This term means using game elements and mechanisms in the 
activities which cannot be strictly classified as games in order to easily master such activities, i.e. to master them in a form of a game.

The factors that encourage the application of games in education should be noted:

- Motivation is more easily accomplished because the learning process as well as the adoption of certain procedures is replaced with natural acceptance of the rules for the operation of the game you want to play. So it could be used for performance assessment.

- Higher levels of learning are more easily accomplished with different levels of play, as opposed to classical learning where books are usually given in one, possibly two, or very rarely on many levels.

- The desire to master as many levels of the game as possible makes learning fun for students, so motivation comes spontaneously.

Good teachers tend to make their stories and performances interesting for their students and to involve them in the topic. In the case of games, participants are spontaneously and automatically involved, because of the very nature of games.

Participants are not passive game players, but they influence the game outcome by taking actions and making decisions (obviously, in traditional learning, that it is not possible) (Bhasin, 2014).

In many situations where there is a risk of harm to health or material goods, games can replace practice in the real environment and be a good precursor to practice in the real environment.

Many authors have noted that games can teach effectively about various types of risks, or about their minimization without "collateral damage in the first operating performances" that occursin traditional learning. This can be seen in more detail in papers (Ambroseet al, 2010), (Holmes, Gardner, 2006), (Tonks, 2002, pp.177-194).

Games can prepare for unexpected (stochastic) situationsin the working environment (Trybus, 2015), (Geuting, 2000), (Lunce, 2004, p.29).

Many authors dealt with an analysis of learning through play and achieving results in real life simulations with an understanding of situations in real life (Fink et al, 2014, pp.141-152), (Finkelstein et al, 2005, pp.1-8), (Hunzeker, Harkness, 2014, pp.513-517), (Leger et al, 2011, pp.39-53), (Prensky, 2001, p.128). All previous authors prefer this way of learning to the traditional way.

The paper (Buck, 2013) recommends this method of learning in the following fields: engineering, economics, medicine, marketing, management, political science, international relations, foreign languages, etc. 


\section{Multi-criteria analysis of studies and learning}

In this paper, a multi-criteria analysis (optimization) will be used for the evaluation of possible study forms that seeks to take advantage of information technology in order to modernize and improve teaching and learning process.

Evaluation is carried out so as to observe four alternatives, but there may be more of them.

\section{ALTERNATIVES}

$A_{1}$ : Teaching is classical during the entire studies.

$A_{2}: A_{1}$ until the last semester when the simulations course is introduced and then in the form of games students are doing case studies. At the end of the semester, the case studies are evaluated as a graduation thesis.

$A_{3}$ : Teaching is classical during the first half of studies. At the beginning of the second half of studies, the course on simulations is introduced where the basic principles and their applications are taught. After this course, other subjects are also taught using games (simulations). In the last semester, students use case studies to work with simulations (games) and that is considered as a graduation thesis.

$A_{4}$ : Teaching is classical just at the beginning of the studies and in the courses where it is more convenient. During the first course in the subject of information technologies, students are introduced to the basic concepts of simulations and games. In the cases where it is possible to make a combination of classical teaching and computer games, as a rule, the learning process is faster and more efficient. In the last semester, simulations are used with case studies to give students real life practice.

\section{CRITERIA}

$C_{1}$ : Assessment of achieved average results in learning

$C_{2}$ : Rating of courses (advantage for organizers)

$C_{3}$ : Assessment of the acceptability of studying modes for students

$C_{4}$ : Assessment of the opportunities to integrate graduates in the future business environment

$C_{5}$ : Assessment of time required to achieve the desired results in learning

$C_{1}$ : Rating the proficiency of students to understand risks when making decisions in the real environment and to minimize risks. 
It should be noted that more criteria can be applied; for example, the following criterion could be added:

Assessment of the acceptability of modes of studying by potential students.

This criterion would be very important for decision-making of the management of higher education institutions regarding types of studying. However, it was not taken into account here since the authors did nothave adequate data.

It would also be possible to reduce the number of criteria, or togroup some criteria which are overlapping (for example $\mathrm{C}_{4}$ and $\mathrm{C}_{6}$ ), but we believe they are better organizedin this way, and any overlapping of the criteria is eliminated by the appropriate choice of the weight coefficients.

The evaluation matrix was created in cooperation with the management of the Faculty of Health, Legal and Business Studies, Singidunum University, which introduced this form of study within its study programmes (A2 alternative), based on the results of the research carried out among the students for which this form of teaching was introduced (research performed by the teaching staff who teach business simulations).

The weight coefficients of criteria were determined andthe evaluation was carried out using a new method presented in the article (Miljković et al, 2017). The control of the results was performed using some other methods of multi-criteria analysis given in the literature (Nikolić, Borović, 1996), (Radojičić, Žižović, 1998) and the results are in a line with the previous ones.

Table 1 - Criteria values by alternatives

Таблица 1 - Значения альтернатив по критериям

Табела 1 - Вредности алтернатива по критеријумима

\begin{tabular}{|c|c|c|c|c|c|c|}
\hline & $C_{1}$ & $C_{2}$ & $C_{3}$ & $C_{4}$ & $C_{5}$ & $C_{6}$ \\
\hline$A_{1}$ & 6 & 9 & 5 & 7 & 4 & 4 \\
\hline$A_{2}$ & 7 & 8 & 6 & 8 & 5 & 7 \\
\hline$A_{3}$ & 8 & 7 & 7 & 8 & 7 & 7 \\
\hline$A_{4}$ & 9 & 6 & 9 & 8 & 9 & 8 \\
\hline
\end{tabular}

If we assume that all criteria are equally numerically important, and that they occur in the following order

$$
C_{1} \rightarrow C_{2} \rightarrow C_{3} \rightarrow C_{4} \rightarrow C_{5} \rightarrow C_{6},
$$

then 
$\rho_{1}=\rho_{2}=\rho_{3}=\rho_{4}=\rho_{5}=\rho_{6}=\frac{1}{6}$,

and the order of the alternatives is

$A_{4} \rightarrow A_{3} \rightarrow A_{2} \rightarrow A_{1}$.

If we assume that the most important criteria is $C_{2}$ and that the complete sequence of criteria is

$C_{2} \rightarrow C_{1} \rightarrow C_{3} \rightarrow C_{4} \rightarrow C_{5} \rightarrow C_{6}$,

and that the criteria $C_{1}, C_{2}, C_{3}, C_{4}, C_{5}$ and $C_{6}$ have the same numerical value, for example,

$\rho_{2}=0,9, \rho_{1}=\rho_{3}=\rho_{4}=\rho_{5}=\rho_{6}=0,02$.

we get the following sequence of the alternatives

$A_{1} \rightarrow A_{2} \rightarrow A_{3} \rightarrow A_{4}$.

It is interesting that the same arrangement is obtained if $\rho_{2} \geq 0.58333 \ldots$ and $\rho_{1}=\rho_{3}=\rho_{4}=\rho_{5}=\rho_{6}$. Also, it can be easy to get $A_{2}$ before other alternatives $0,5 \leq \rho_{2}<0.58333 \ldots$, then that $A_{4}$ is ahead of other alternatives for $\rho_{2}<0,5$ and $\rho_{1}=\rho_{3}=\rho_{4}=\rho_{5}=\rho_{6}$.

If we assume that the most important is one of the following criteria: $C_{1}$ or $C_{3}$ or $C_{5}$ or $C_{6}$, then $A_{4}$ is the best alternative.

In the event that the order of the criteria is $C_{4} \rightarrow C_{2} \rightarrow C_{1}$, and then the rest of them, one can find a situation that $A_{3}$ is the best alternative; for example, for $\rho_{4}=0.6, \rho_{2}=0.18, \rho_{1}=0.145, \rho_{3}=\rho_{5}=\rho_{6}=0.025$, the order of the alternatives is

$A_{3} \rightarrow A_{2} \rightarrow A_{4} \rightarrow A_{1}$.

\section{Conclusion}

To implement computer games in teaching, it is necessary to have prepared teaching staff for this and appropriate software (games and simulations) which, as a rule, must continuously improve. These improvements should be made by teachers that already work on existing courses in a "classical way". The advantages of this mode can be seen in business situations, management case studies, in various fields where randomized situations can happen, like in medicine, veterinary medicine, 
agriculture, etc. Also, they can be applied in many other significant fields such as military education, especially for training reserve officers.

\section{References}

Ambrose, S., Bridges, M., Dipietro, M., Lovett, M., Norman, M., \& Mayer, R., 2010. How Learning Works: Seven Research-Based Principles for Smart Teaching. San Francisco, CA: Jossey-Bass.

Bhasin, K., 2014. Gamification, Game-based Learning, Serious Games: Any Difference? Learning Solutions Magazine. [Internet]. Available at: http://www.learningsolutionsmag.com/articles/1337/gamification-game-basedlearning-serious-games-any-difference.

Buck, W., 2013. Business Ethics Simulations: The Role of Reflection, Intentionality and Assessment. In: Society for Business Ethics 2013 Annual Conference, Miami. [Internet]. Available at: https://www.academia.edu/3567938/Business_Ethics_Simulations_The_Role_of _Reflection_Intentionality_and_Assessment.

Fink, S., Kiili, K., \& Bullinger, A., 2014. Measuring Game Experience and Learning Effects of Business Games. In: Conference of the International Simulation and Gaming Association, Dornbirn, pp.141-152.

Finkelstein, N.D., Adams, W.K., Keller, C.J., Kohl, P.B., Perkins, K.K., Podolefsky, N., Reid, S., LeMaster, R., 2005. When learning about the real world is better done virtually: A study of substituting computer simulations for laboratory equipment. Physical Review, Special Topics: Physics Education Research, 1(1), pp.1-8. Available at: http://dx.doi.org/10.1103/PhysRevSTPER.1.010103.

Geuting, M., 2000. Soziale Simulation und Planspiel in pädagogischer Perspektive. Eine Bestandsaufnahme der internationalen Diskussion Münster. Hamburg - London: LIT Verlag.

Holmes, B., \& Gardner, J., 2006. E-learning concepts and practice. London: Sage publications, p.5.

Hunzeker, M., \& Harkness, K., 2014. The Strategy Project: Teaching Strategic Thinking through Crisis Simulation. PS: Political Science \& Politics, 47(2), pp.513-517. Available at: http://dx.doi.org/10.1017/S104909651400047X.

Leger, P.M., Charland, P., Feldstein, H.D., Robert, J., Babin, G., \& Lyle, D., 2011. Business Simulation Training in Information Technology Education: Guidelines for New Approaches in IT Training. Journal of Information Technology Education, 10(1), pp.39-53.

Lunce, L.M., 2004. Computer Simulations in Distance Education. International Jurnal of Instructional Technology \& Distance Learning, 1(10), p.29.

Miljković, B., Žižović, M.R., Petojević, A., \& Damljanović, N., 2017. New Weighted Sum Model. Filomat (accepted for publication). 
Miljković, B.D., Petojević, A.V., \& Žižović, M.R., 2016. Monitoring the effect of motivation on mastering knowledge and skills in distance learning systems. Vojnotehnički glasnik/Military Technical Courier,64(4), pp.1009-1032. Available at: http://dx.doi.org/10.5937/vojtehg64-10687.

Nikolić, I., \& Borović, S., 1996. Višekriterijumska optimizacija (in Serbian). Beograd: Centar vojnih škola Jugoslavije.

Prensky, M., 2001. Digital game-based learning. New York: McGraw Hill, p.128.

Radojičić, M., \& Žižović, M.R., 1998. Applications of methods of multicriteria analysis in business decision-making (in Serbian).Čačak, Serbia: Technical faculty. Monograph.

Shank, P., 2013. eLearning Guild Research: Got Game? Learning Solutions Magazine. [Internet]. Available at: http://www.learningsolutionsmag.com/articles/1227/elearning-guild-research-gotgame. Accessed:18Jun 2016.

Tonks, D., 2002. Using marketing simulations for teaching and learning: Reflections on an evolution. Active Learning in Higher Education, 3(2), pp.177194, July.

Trybus, J., 2015. Game-Based Learning: What it is, Why it Works, and Where it's Going. New Media Institute. [Internet]. Available at: http://www.newmedia.org/game-based-learning--what-it-is-why-it-works-andwhere-its-going.html.Accessed:20Jun 2016.

МНОГОКРИТЕРИАЛЬНЫЙ АНАЛИЗ ВОЗМОЖНОСТЕЙ ПРИМЕНЕНИЯ КОМПЬЮТЕРНЫХ ИГР В ПРОЦЕССЕ ОБУЧЕНИЯ

Малиша Р. Жижович, Катарина Г. Плечич

Университет Сингидунум, г. Белград, Факультет управления

здравохранением, бизнеса и юридических наук, г. Валево, Республика

Сербия

ОБЛАСТЬ: математика

ВИД СТАТЬИ: оригинальная научная статья

ЯЗЫК СТАТЬИ: английский

Резюме:

В данной статье представлен многокритериальный анализ отдельных возможностей по организации образовательных программ в ВУЗ-ах. Вследствие широкого применения современных информационных технологий, традиционная образовательная система требует больших перемен. Одной составляющей таких перемен является внедрение специально разработанных компьютерных игр, симулирующих реальную деловую обстановку. Традиционные пассивные образовательные программы сосредоточены на отдельные и узко направленные знания, в конечном итоге, испытуемые представляют заученные знания, приобретенныена основании услышанного. Однако такого 
рода усвоение знаний, даже в случае, когда они хорошо усвоены, не предусматривают поведенческих аспектов, как самого учащегося, так и его будущих деловых партнеров. С помощью игр создается ощущение участия в реальных событиях, они лучше мотивируют учащихся u делают процесс обучение интересным. Интерактивный фрактор игр приводит к высокой степени ангажированности самих участников, при этом аспект развлечения постепенно опускается, делая игру серьезным инструментом в процессе обучения. От обычных компьютерных игр дидактические, в первую очередь, отличаются целью, которая заключается в усвоении знаний. В такого рода дидактических компьютерных играх, участник занимает активную позицию, так как от его решений зависит развитие и исход игры.

Ключевые слова: многокритериальный анализ, критерии, критерии сложности, игры, моделирование.

\section{ВИШЕКРИТЕРИЈУМСКА ОЦЕНА МОГУЋИХ ПРИМЕНА РАЧУНАРСКИХ ИГАРА У НАСТАВИ}

Малиша Р. Жижовић, Катарина Г. Плећић

Универзитет Сингидунум Београд, Факултет здравствених, правних и пословних студија, Ваљево, Република Србија

ОБЛАСТ: математика

ВРСТА ЧЛАНКА: оригинални научни чланак

ЈЕЗИК ЧЛАНКА: енглески

\section{Сажетак:}

У раду се даје вишекритеријумска оцена неколико могућих приступа организовању студија. Захваљујући све широј употреби савремених информационих технологија, традиционални образовни систем суочава се са великим променама. Једна од њих је и развој озбиљних игара које симулирају рад реалних пословних окружења.

Традиционални, пасивни приступ образовању обучава нас за неке уске процедуре, а затим врши евалуацију на основу нашег сећања на оно што нам је речено. Чак и када смо успешно савладали чињенице и процедуре, наше понашање у правим животним ситуацијама остаје непроверено. Игре покушавају да реше проблем, мотивишу и промовишу учење. Њихов интерактивни аспект доводи до високе укључености самих учесника у активности игре, па оне више немају сврху искључиво забаве већ постају озбиљан алат за учење. Од класичних забавних игара одваја их првенствено другачији циљ, тј. могућност да се учеснику игре, поред забаве, пружи и едукативна компонента. Такође, учесник није пасивни играч већ својим одлукама и поступцима 
директно може утицати на ток игре, доводећи до добрих или лоших резултата.

Кључне речи: вишекритеријумска анализа, критеријуми, тежина критеријума, игре, симулације.

Paper received on / Дата получения работы / Датум пријема чланка: 23.01.2017.

Manuscript corrections submitted on / Дата получения исправленной версии работы / Датум достављања исправки рукописа: 01.04.2017.

Paper accepted for publishing on / Дата окончательного согласования работы / Датум коначног прихватања чланка за објављивање: 03.04.2017.

(c) 2017 The Authors. Published by Vojnotehnički glasnik / Military Technical Courier (www.vtg.mod.gov.rs, втг.мо.упр.срб). This article is an open access article distributed under the terms and conditions of the Creative Commons Attribution license

(http://creativecommons.org/licenses/by/3.0/rs/).

(C) 2017 Авторы. Опубликовано в «Военно-технический вестник / Vojnotehnički glasnik / Military Technical Courier» (www.vtg.mod.gov.rs, втг.мо.упр.срб). Данная статья в открытом доступе и распространяется в соответствии с лицензией «Creative Commons» (http://creativecommons.org/licenses/by/3.0/rs/).

( 2017 Аутори. Објавио Војнотехнички гласник / Vojnotehnički glasnik / Military Technical Courier (www.vtg.mod.gov.rs, втг.мо.упр.срб). Ово је чланак отвореног приступа и дистрибуира се у складу са Creative Commons licencom (http://creativecommons.org/licenses/by/3.0/rs/). 